\title{
Detection and Discrimination of Pratylenchus neglectus and P. thornei in DNA Extracts from Soil
}

\author{
Guiping Yan and Richard W. Smiley, Oregon State University, Columbia Basin Agricultural Research Center, Pen- \\ dleton 97801; Patricia A. Okubara, United States Department of Agriculture-Agricultural Research Service \\ (USDA-ARS), Root Disease and Biological Control Research Unit, Pullman, WA 99164; Andrea Skantar, USDA- \\ ARS, Nematology Laboratory, Beltsville, MD 20705; and Sandra A. Easley, Jason G. Sheedy, and Alison L. \\ Thompson, Oregon State University, Columbia Basin Agricultural Research Center, Pendleton
}

\begin{abstract}
Yan, G. P., Smiley, R. W., Okubara, P. A., Skantar, A., Easley, S. A., Sheedy, J. G., and Thompson, A. L. 2008. Detection and discrimination of Pratylenchus neglectus and P. thornei in DNA extracts from soil. Plant Dis. 92:1480-1487.

A species-specific polymerase chain reaction (PCR) method was developed to detect and identify the root-lesion nematodes Pratylenchus neglectus and P. thornei from soil. A primer set was designed from Pratylenchus 28S rRNA gene sequences of the D3 expansion domain. Primer specificity was confirmed with 23 isolates of 15 nematode species and other plant-parasitic and non-plant-parasitic nematodes typically present in the soil communities, and with six fungal species commonly associated with wheat root rot. DNA obtained using a commercially available kit and a method developed in our laboratory gave comparable amplification. PCR conditions were optimized and the two species were differentiated by PCR products of $144 \mathrm{bp}$ for $P$. neglectus and $288 \mathrm{bp}$ for $P$. thornei. With this assay, we detected a single juvenile in $1 \mathrm{~g}$ of sterile, inoculated soil. Examination of 30 field soil samples revealed that this method was applicable to a range of soils naturally infested with these two pathogens in Oregon. This PCR-based method is rapid, efficient, and reliable, does not require expertise in nematode taxonomy and morphology, and could be used as a rapid diagnostic tool for commercial and research applications for disease forecasting and management.
\end{abstract}

Additional keywords: detection sensitivity, DNA extraction, DNA purification

Root-lesion nematodes, Pratylenchus spp., are widely distributed and economically important migratory endoparasites of many plant species (8). Recently, Pratylenchus neglectus and $P$. thornei were shown to be widespread in wheat fields in Oregon and Washington (27), and Idaho (31). High populations of these species in commercial fields have reduced yields of intolerant wheat cultivars by as much as 60\% (29,30). Pratylenchus spp. populations exceeding the threshold for economic damage are now thought to occur in up to $60 \%$ of wheat fields in the Pacific Northwest. $P$. neglectus is more widely distributed than $P$. thornei, but mixed populations have been found within the same field (27).

The best approach to control damage from lesion nematodes is to grow cultivars

Corresponding author: G. P. Yan

E-mail: guiping.yan@oregonstate.edu

Accepted for publication 3 August 2008.

doi:10.1094/PDIS-92-11-1480

(C) 2008 The American Phytopathological Society that are both resistant and tolerant $(28,34,36)$. Individual wheat cultivars differ in tolerance to these nematodes; cultivars that exhibit tolerance to $P$. neglectus are not necessarily tolerant to $P$. thornei, and vice versa. Mechanisms for resistance to these species are also under different species-specific genetic controls (36). Therefore, optimal cultivar selection requires that the lesion nematode species present in each field or region be accurately identified. Identification of these species will become even more important if current biofuels initiatives result in additional production of biofuel crops. For example, increasing canola acreage has the potential to significantly affect the level of damage to subsequent wheat crops, depending on the Pratylenchus spp. present. Canola may increase populations of $P$. neglectus but is less likely to increase populations of $P$. thornei (36).

Distinction between $P$. neglectus and $P$. thornei based on morphological characteristics requires detailed microscopic measurements by an experienced nematologist. Morphological diagnosis may be further complicated by difficulties in distinguish- ing three key diagnostic features (lip annules, tail shape, and vulva position). For example, vulval position has an overlapping range for these species, requiring measurements of multiple specimens to determine a mean for the ratio of vulval position to body length $(12,13)$. In addition, morphological identification is limited to examination of mature adult females of these parthenogenic species. The largest commercial nematode diagnostic laboratory in the Pacific Northwest quantifies Pratylenchus spp. at the genus but not species level due to issues relating to reliability and expense. However, the lab is equipped and staffed for PCR diagnostic services using plant and soil DNA. A quick, reliable, and inexpensive molecular method that is amenable to highthroughput diagnostic labs is needed for distinguishing P. neglectus and P. thornei. A commercial testing program in South Australia provides DNA-based diagnostic services; however, the protocols are currently proprietary (21). A publically available procedure is needed to increase the level of service and diagnostic efficiency in laboratories elsewhere in the world, and particularly to facilitate more precise surveys of species distribution in the Pacific Northwest where $P$. neglectus and $P$. thornei are widespread and damaging.

Polymerase chain reaction (PCR)-based techniques have been reported for identifying species of Pratylenchus (22,32,37). The combination of PCR and restriction fragment-length polymorphism (RFLP) has been used to discriminate Pratylenchus spp. $(32,37)$, but the RFLP portion of the test requires an additional step and time that is not amenable to commercial, highthroughput applications. PCR amplification with species-specific primers followed by gel electrophoresis has been used effectively for discrimination of some plantparasitic nematodes $(1,3,4,6,18,35,40)$. AlBanna et al. (1) distinguished $P$. neglectus and $P$. thornei along with four other Pratylenchus spp. using PCR and speciesspecific primers derived from the internal variable portion of the D3 expansion region of the $28 \mathrm{~S}$ rDNA. Carrasco- 
Ballesteros et al. (6) identified P. thornei from different life stages of the nematode using PCR and specific sequencecharacterized amplified region (SCAR) primers derived from a randomly amplified DNA fragment.

Although the PCR-based methods described above distinguished $P$. neglectus from $P$. thornei, they were designed to use DNA extracted from nematode cultures or isolated individuals. There is a clear need for quick diagnostic methods that do not require time-consuming nematode extraction (38), such as are currently available for detecting plant-pathogenic bacteria and fungi in soil $(9,11,15)$. There are few reports on the use of molecular techniques for detecting and distinguishing nematodes species in soil. Atkins et al. (4) detected false root-knot nematodes (Nacobbus spp.) from soil and potato tubers using PCR with species-specific primers and DNA extracted with a soil DNA extraction kit. Iwahori et al. (14) detected root-knot nematodes (Meloidogyne spp.) from soil using PCR-RFLP with DNA isolated with a modified commercial soil DNA kit.

The objectives of this study were to develop a quick, sensitive, reliable, and nonproprietary diagnostic method for identifying $P$. neglectus and $P$. thornei directly from soil, and to determine whether the method was applicable to a wide range of soils inhabited by these nematodes at a range of population densities.

\section{MATERIALS AND METHODS}

DNA extraction from nematodes. Nematodes were extracted from soil samples using the Whitehead tray method (39). This method relies principally on the active movement of migratory nematodes from the moist soil sample into the surrounding water. Adult females were morphologically identified $(12,13)$ as either $P$. neglectus (two lip annules, pointed but still round tail, and vulva position ratio on body at 76 to $87 \%$ ) or P. thornei (three lip annules, slightly truncated tail on end, and vulva ratio at 73 to $80 \%$ ), and then placed onto surface-sterilized carrot disks to establish pure cultures. DNA was extracted from nematodes following the protocol described by Waeyenberge et al. (37), with some modifications. Ten nematodes of mixed juvenile and adult stages were handpicked using a dental pick, put into $20 \mu \mathrm{l}$ of sterilized nanopure water on a concave glass slide, and cut into two pieces under a dissecting microscope. Then, $10 \mu$ of sus- pension containing nematode pieces were pipetted into a 0.2-ml sterile Eppendorf tube with $8 \mu$ l of lysis buffer $(500 \mathrm{mM}$ $\mathrm{KCl} ; 100 \mathrm{mM}$ Tris-Cl, $\mathrm{pH} 8.3 ; 15 \mathrm{mM}$ $\mathrm{MgCl}_{2} ; 10 \mathrm{mM}$ dithiothreitol [DTT]; $4.5 \%$ Tween 20; and $0.1 \%$ gelatin). The tube contents were frozen at $-20^{\circ} \mathrm{C}$ for at least $20 \mathrm{~min}$, then thawed, and $2 \mu \mathrm{l}$ of proteinase $\mathrm{K}$ at $600 \mu \mathrm{g} / \mathrm{ml}$ was added. The tubes were incubated at $65^{\circ} \mathrm{C}$ in a water bath for $1 \mathrm{~h}$, and consecutively at $95^{\circ} \mathrm{C}$ for $10 \mathrm{~min}$ to inactivate proteinase $\mathrm{K}$. The nematode lysis mix was centrifuged at $16,000 \times g$ for $5 \mathrm{~min}$ and the supernatant was transferred to a new $0.2-\mathrm{ml}$ tube and stored in $-20^{\circ} \mathrm{C}$ until used as the DNA template.

Primer selection and evaluation for specificity. The species-specific forward primer PTHO and the common reverse primer D3B described by Al-Banna et al. (1) were used to identify P. thornei (Table 1). The species-specific forward primer PNEG-F1 and the common reverse primer D3B5 were designed to identify P. neglectus. PNEG-F1 was designed based on the variable region in the alignment of the $28 \mathrm{~S}$ rRNA D3 expansion domains obtained from GenBank. D3B5 was selected from the conserved region of the same D3 expansion domain in order to produce a PCR fragment different in size from that produced with DNA from $P$. thornei. These primers were analyzed for annealing temperature, GC content, dimers, and hairpin loops using GeneRunner (version 3.05; Hastings Software, Inc., Hudson, NY), and synthesized by Invitrogen (Carlsbad, CA).

Six isolates of $P$. neglectus and two isolates of $P$. thornei from Oregon, Washington, Montana, and Idaho (Table 2) were used to examine the specificity of the Pratylenchus primers. Isolates of five other Pratylenchus spp. and three Meloidogyne spp. (Table 2) were tested for primer specificity. Five plant-parasitic nematode species (Heterodera avenae, H. filipjevi, Tylenchorhynchus sp., Merlinius brevidens, and Paratylenchus sp.), three nematode communities frequently found in wheat fields in eastern Oregon, and six fungal species commonly associated with wheat root diseases were also used as controls (Table 2). PCR reactions of $25 \mu \mathrm{l}$ contained the DNA template $(5 \mu \mathrm{l}), 0.75$ units of Taq polymerase (Roche, Mannheim, Germany), $200 \mu \mathrm{M}$ dNTPs, $0.5 \mu \mathrm{M}$ each primer, 1× PCR buffer with $1.5 \mathrm{mM}$ $\mathrm{MgCl}_{2}$, and $1 \times$ Cresol Red in $20 \%$ glycerol. PCR amplification was performed in a MyCycler Thermal Cycler (Bio-Rad, Richmond, CA) as follows: $95^{\circ} \mathrm{C}$ for $3 \mathrm{~min}$ followed by 35 cycles of $95^{\circ} \mathrm{C}$ for $30 \mathrm{~s}$, $60^{\circ} \mathrm{C}$ (PNEG-F1/D3B5) or $62^{\circ} \mathrm{C}$ (PTHO/D3B) for $30 \mathrm{~s}$, and $72^{\circ} \mathrm{C}$ for $30 \mathrm{~s}$, with a final extension at $72^{\circ} \mathrm{C}$ for $7 \mathrm{~min}$. PCR products were separated in $2 \%$ standard agarose gels stained with ethidium bromide. Molecular size was estimated by a 100-bp DNA ladder (Roche). Band pattern was photographed under UV light using a Polaroid digital camera, and analyzed by the Polaroid PhotoMAX Pro program (Polaroid, Bedford, MA). This experiment was performed four times.

To expand specificity evaluation to additional nontarget nematode species that could not be obtained in culture or DNA based on requests, an in silico analysis was conducted using GenBank D3 expansion sequences from four Pratylenchus spp. and four nematode genera and the computer software PrimerSelect 5.00 (DNASTAR, Inc, Madison, WI). Primer specificity was determined by the primer-template duplex stability values $(\Delta \mathrm{G})$ as described by Schroeder et al. (26) and Okubara et al. (20). The Pratylenchus spp. were P. vulnus (U47547 and AJ545020), P. hexincisus (U47554 and AF303949), P. brachyurus (U47553), and $P$. coffeae (U47552, AF170428, and AF170436). The nematode species in other genera were Meloidogyne incognita (AY355417), Globodera tabacum solanacearum (AF393846), $G$. pallida (AF393843), Paratrichodorus pachydermus (AM180727), P. anemones (AJ781505), and H. glycines (DQ328692).

DNA extraction from soil and DNA purification by polyvinylpolypyrrolidone powder column. Various extraction methods were evaluated by examining and comparing band intensity of PCR amplification on agarose gel. Total genomic DNA was extracted from soil using two commercial soil DNA extraction kits, FastDNA SPIN Kit for Soil (Bio101, La Jolla, CA) and PowerSoil DNA Isolation Kit (MoBio, Carlsbad, CA), according to the manufacturers' recommendations. Four buffers prepared in the laboratory also were compared. These were designated buffer $\mathrm{A}(\mathrm{pH}$ $8.0, \quad 30 \mathrm{mM} \quad \mathrm{Na}_{2} \mathrm{HPO}_{4}$ and $90 \mathrm{mM}$ $\left.\mathrm{NaH}_{2} \mathrm{PO}_{4}\right)$ (38), buffer B (200 mM Tris$\mathrm{HCl}, \mathrm{pH} 8.5 ; 250 \mathrm{mM} \mathrm{NaCl} ; 25 \mathrm{mM}$ EDTA; $0.5 \%$ sodium dodecyl sulfate [SDS]) (25), buffer C (500 mM KCl; 100 $\mathrm{mM}$ Tris-Cl, $\mathrm{PH} 8.3 ; 15 \mathrm{mM} \mathrm{MgCl} 2 ; 10$ mM DTT; $4.5 \%$ Tween $20 ; 0.1 \%$ gelatin) (37), and buffer D (equal amounts of

Table 1. Sequences of polymerase chain reaction (PCR) primers and the expected size of PCR products to discriminate Pratylenchus neglectus and P. thornei

\begin{tabular}{lllcl}
\hline Species & Primer name $^{\mathbf{a}}$ & \multicolumn{1}{c}{ Sequence (5'-3') } & Band size (bp) & Reference \\
\hline$P$. neglectus & F: PNEG-F1 & CGCAATGAAAGTGAACAATGTC & 144 & This study \\
& R: D3B5 & AGTTCACCATCTTTCGGGTC & $\ldots$ & This study \\
P. thornei & F: PTHO & GAAAGTGAAGGTATCCCTCG & 288 & 1 \\
& R: D3B & TCGGAAGGAACCAGCTACTA & $\ldots$ & $1,2,7$ \\
\hline
\end{tabular}

${ }^{\mathrm{a}} \mathrm{F}=$ forward primer and $\mathrm{R}=$ reverse primer. 
phosphate buffer [100 mM NaH $\mathrm{PO}_{4}, \mathrm{pH}$ 8.0] and SDS buffer [ $100 \mathrm{mM} \mathrm{NaCl} ; 500$ $\mathrm{mM}$ Tris, $\mathrm{pH} 8.0 ; 10 \%$ SDS]) (11). DNA extractions with these buffers were performed after mechanical lysis using lysing matrix tubes provided in the FastDNA SPIN Kit, processed in a FastPrep FP120 machine (Bio101, Savant) for $30 \mathrm{~s}$ at a speed of $5.5 \mathrm{~m} / \mathrm{s}$. Crude DNA extracts were then purified using High Pure spin filters (Roche) that contained waterinsoluble polyvinylpolypyrrolidone (PVPP; Sigma-Aldrich, St. Louis) powder.

To replace the expensive lysing matrix provided in FastDNA SPIN Kit, the effect of glass beads was assessed, including 0.20 $\mathrm{g}$ of $1.0-\mathrm{mm}$ glass beads (Research Product International Corp., Mt. Prospect, IL) with one ceramic sphere $(6.4 \mathrm{~mm}$; Fisher Scientific, Pittsburgh), $0.80 \mathrm{~g}$ of $1.0-\mathrm{mm}$ glass beads, $0.53 \mathrm{~g}$ of $1.0-\mathrm{mm}$ glass beads, and $0.60 \mathrm{~g}$ of $1.0-\mathrm{mm}$ glass beads combined with $0.15 \mathrm{~g}$ of $0.1-\mathrm{mm}$ glass beads.

Extraction of DNA from soil often results in co-extraction of humic substances that inhibit DNA polymerase during PCR amplification. To remove humic substances prior to PCR reaction, PVPP columns were prepared as a substitute for spin filters provided in the extraction kits. A hole (1 $\mathrm{mm}$ ) was made in the bottom of a $0.5-\mathrm{ml}$ tube and was covered by small pieces $(0.005 \mathrm{~g})$ of glass wool (Corning, NY) using a forceps. The tube was inserted into a $1.5-\mathrm{ml}$ tube with the lid removed. Dry PVPP powder (0.05 g; Sigma-Aldrich) was added to the $0.5-\mathrm{ml}$ tube. The PVPP column was conditioned by the addition of $100 \mu \mathrm{l}$ of sterilized nanopure water $\left(\mathrm{SNPH}_{2} \mathrm{O}\right)$ twice, each followed by $3 \mathrm{~min}$ of centrifugation at $400 \times \mathrm{g}$. A final spin for $30 \mathrm{~s}$ was performed just before use to remove residual water.

The optimized protocol developed in this study is as follows. Soil was added to a 2.0-ml screw-cap tube (Bio-Rad) with glass beads $(0.53 \mathrm{~g}, 1 \mathrm{~mm})$. Buffer D (300 $\mu l$ of each phosphate buffer and SDS buffer) was added and the tube was inverted several times. Chloroform:isoamyl alcohol (400 $\mu \mathrm{l}, 24: 1)$ was added to the tube and shaken in a FastPrep FP120 machine for $30 \mathrm{~s}$ at a speed of $5.5 \mathrm{~m} / \mathrm{s}$. The tube was centrifuged for $5 \mathrm{~min}$ at $16,000 \times$ $g$ and the supernatant (less than $600 \mu \mathrm{l}$ ) transferred to a clean $1.5-\mathrm{ml}$ centrifuge tube. Then, $300 \mu \mathrm{l}$ of cold NaOAc ( $3 \mathrm{M}$, $\mathrm{pH}$ 5.2) was added and, following incubation $\left(5 \mathrm{~min}\right.$ at $\left.-20^{\circ} \mathrm{C}\right)$, the suspension was cleared by centrifugation for $5 \mathrm{~min}$ at $16,000 \times g$. The supernatant (up to $650 \mu \mathrm{l}$ ) was transferred to a clean tube. DNA was subsequently precipitated with $600 \mu \mathrm{l}$ of cold isopropanol for $20 \mathrm{~min}$ at room temperature and collected by centrifugation at $16,000 \times g$ for $5 \mathrm{~min}$. The resulting pellet was rinsed with $70 \%$ ethanol and centrifuged for $5 \mathrm{~min}$ at $16,000 \times \mathrm{g}$. The DNA pellet was air dried and dissolved in $100 \mu \mathrm{l}$ of $\mathrm{SNPH}_{2} \mathrm{O}$. The crude DNA solution was added to the PVPP column described above, followed by centrifugation at $400 \times$ $g$ for $1 \mathrm{~min}$, incubation at room temperature for $2 \mathrm{~min}$, and a final centrifugation at $400 \times g$ for $5 \mathrm{~min}$. The purified DNA in the tube was then used for PCR.

Optimization of PCR conditions with DNA extracted from soil. To improve PCR amplification for $P$. neglectus, the effect of bovine serum albumin (BSA) as a PCR enhancer was assessed. A BSA solution of $10 \mu \mathrm{g} / \mu \mathrm{l}$ was added to PCR reaction mixtures to make final concentrations of 0 , $0.1,0.4,0.8$, and $1.0 \mu \mathrm{g} / \mu \mathrm{l}$. Additional

Table 2. Isolates of Pratylenchus spp. and other nematode and fungal species used to examine the species-specific polymerase chain reaction primers for distinguishing $P$. neglectus and $P$. thornei

\begin{tabular}{|c|c|c|c|c|c|}
\hline Species ${ }^{\mathbf{a}}$ & $\mathbf{N}$ or $\mathbf{F}^{\mathbf{b}}$ & Isolate & Origin & Host & Source $^{c}$ \\
\hline Pratylenchus neglectus & $\mathrm{N}$ & Pn1 & La Grande, OR & Wheat & R. Smiley \\
\hline P. neglectus & $\mathrm{N}$ & $\operatorname{Pn} 2$ & Lind, WA & Wheat & R. Smiley \\
\hline P. neglectus & $\mathrm{N}$ & Pn3 & Moro, OR & Wheat & R. Smiley \\
\hline P. neglectus & $\mathrm{N}$ & Pn4 & Heppner, OR & Wheat & R. Smiley \\
\hline P. neglectus & $\mathrm{N}$ & Pn5 & Great Falls, MT & Wheat & A. Dyer \\
\hline P. neglectus & $\mathrm{N}$ & Pn6 & Canyon County, ID & Potato & S. Hafez \\
\hline P. thornei & $\mathrm{N}$ & Pt1 & Pendleton, OR & Wheat & R. Smiley \\
\hline P. thornei & $\mathrm{N}$ & Pt2 & Pendleton, OR & Wheat & R. Smiley \\
\hline P. agilis & $\mathrm{N}$ & 031302 & Wye, MD & Corn & L. Carta \\
\hline P. crenatus & $\mathrm{N}$ & 012204 & Clarksville, MD & Grass & Z. Handoo \\
\hline P. zeae & $\mathrm{N}$ & 030204 & North Carolina & Corn & L. Carta \\
\hline P. scribneri & $\mathrm{N}$ & 062805 & Homestead, FL & Tomato & W. Klassen \\
\hline P. scribneri & $\mathrm{N}$ & 032102 & Seneca County, $\mathrm{OH}$ & Corn & L. Carta \\
\hline P. penetrans & $\mathrm{N}$ & 030402 & New York & Corn & L. Carta \\
\hline P. penetrans & $\mathrm{N}$ & 052704 & Wisconsin & Potato & A. MacGuidwin \\
\hline Meloidogyne naasi & $\mathrm{N}$ & 110704 & Linn County, OR & Oat, wheat & K. Merrifield \\
\hline M. chitwoodi & $\mathrm{N}$ & 110504 & Parma, ID & Potato & S. Hafez \\
\hline M. hapla & $\mathrm{N}$ & 070808 & Prosser, WA & Grape & E. Riga \\
\hline Heterodera avenae & $\mathrm{N}$ & $\mathrm{Ha}$ & La Grande, OR & Wheat & R. Smiley \\
\hline H. filipjevi & $\mathrm{N}$ & Hf & La Grande, OR & Wheat & R. Smiley \\
\hline Tylenchorhynchus sp. & $\mathrm{N}$ & Ty & Pendleton, OR & Wheat & S. Easley \\
\hline Merlinius brevidens & $\mathrm{N}$ & $\mathrm{Mb}$ & Pendleton, OR & Wheat & A. Thompson \\
\hline Paratylenchus sp. & $\mathrm{N}$ & $\mathrm{Pa}$ & La Grande, OR & Wheat & G. Yan \\
\hline Nematode community 1 & $\mathrm{~N}$ & $\mathrm{Nc} 1$ & Pendleton, OR & Wheat & J. Sheedy \\
\hline Nematode community 2 & $\mathrm{~N}$ & $\mathrm{Nc} 2$ & Pendleton, OR & Wheat & J. Sheedy \\
\hline Nematode community 3 & $\mathrm{~N}$ & $\mathrm{Nc} 3$ & Pendleton, OR & Wheat & J. Sheedy \\
\hline Bipolaris sorokiniana & $\mathrm{F}$ & $103-18$ & Walla Walla, WA & Wheat & R. Smiley \\
\hline Fusarium culmorum & $\mathrm{F}$ & R5321 & Chatham, Ontario, Canada & Wheat & R. Smiley \\
\hline F. pseudograminearum & $\mathrm{F}$ & $032-06$ & Moro, OR & Wheat & R. Smiley \\
\hline Gaeumannomyces graminis var. tritici & $\mathrm{F}$ & 99401 & Dayton, WA & Wheat & R. Smiley \\
\hline Rhizoctonia oryzae & $\mathrm{F}$ & $2-3-2$ & Wenatchee, WA & Wheat & M. Mazzola \\
\hline R. solani AG-8 & $\mathrm{F}$ & 1727B & Wenatchee, WA & Wheat & M. Mazzola \\
\hline
\end{tabular}

a Nematode communities 1,2 , and 3 were extracted from soils that were not infested with any P. neglectus or P. thornei but were infested with many other plant-parasitic and non-plant-parasitic nematodes; the Whitehead tray method was used for nematode extraction.

${ }^{\mathrm{b}} \mathrm{N}=$ nematodes and $\mathrm{F}=$ fungi.

c Isolates were obtained from R. Smiley, S. Easley, G. Yan, A. Thompson, and J. Sheedy, Oregon State University, Columbia Basin Agricultural Research Center, Pendleton; A. Dyer, Montana State University, Bozeman; S. Hafez, University of Idaho, Southwest Idaho Research and Extension Center, Parma; L. Carta and Z. Handoo, United States Department of Agriculture-Agricultural Research Service (USDA-ARS), Nematology Laboratory, Beltsville, MD; W. Klassen, University of Florida, Tropical Research and Education Center, Homestead; A. MacGuidwin, University of Wisconsin, Department of Plant Pathology, Madison; K. Merrifield, Oregon State University, Department of Botany and Plant Pathology, Corvallis; E. Riga, Washington State University, Irrigated Agriculture Research and Extension Center, Prosser; and M. Mazzola, USDA-ARS, Wenatchee, WA. 
adjustments made to the previously described PCR protocol included decreasing the DNA template from 5 to $1 \mu \mathrm{l}$ for $P$. neglectus and from 5 to $0.2 \mu \mathrm{l}$ for $P$. thornei. The number of PCR cycles was increased from 35 to 40 for both species.

Detection sensitivity of PCR amplification. Soil was inoculated with $P$. neglectus or $P$. thornei to evaluate the sensitivity of PCR detection. A Walla Walla silt loam that was not infested with $P$. neglectus and $P$. thornei was collected from Pendleton, OR and was sieved through a $3-\mathrm{mm}$ sieve. Thereafter, the soil was autoclaved $\left(121^{\circ} \mathrm{C}\right.$, $115 \mathrm{kPa}$ ) two times for $45 \mathrm{~min}$ each to completely kill all living organisms. Juveniles of $P$. neglectus and $P$. thornei were added separately to $1 \mathrm{~g}$ of autoclaved soil using a dental pick with the aid of a microscope. Concentrations of $0,1,2,3$, and 5 juveniles/g of soil were used. Nematode DNA was extracted from the soils using the method developed in this study and DNA was quantified using the NanoDrop ND-1000 Spectrophotometer (Wilmington, DE). The DNA extraction procedure was conducted from eight different samples for each level of inoculation. PCR reactions were performed in duplicate for each independent DNA extraction under the optimum conditions for the soil samples as described above with BSA at a final concentration of $0.8 \mu \mathrm{g} / \mu \mathrm{l}$. The sensitivity for PCR amplification was determined by the ability to detect a minimum number of juveniles/g of soil.

Validation of species identification in soil. Sixteen soil samples were collected from various fields between Heppner and Condon in Morrow County, OR during 2006 and 2007. This location was known to be significantly infested with $P$. neglectus and minimally infested with $P$. thornei. Fourteen soil samples were taken from fields adjacent to the Columbia Basin Agricultural Research Center near Pendleton in Umatilla County, OR during 2006 and 2007. This location was known to be highly infested with $P$. thornei but minimally infested with $P$. neglectus. Nematodes were isolated from approximately $200 \mathrm{~g}$ of fresh moist soil using the Whitehead tray method. Nematodes in $1 \mathrm{ml}$ of extracted suspension were identified and quantified on a nematode-counting slide under a microscope and converted to the number per $\mathrm{kg}$ of soil. Nematodes were identified as $P$. neglectus and $P$. thornei (13), other plant-parasitic nematode genera (17), and non-plant-parasitic nematodes; the numbers for each group are listed in Table 3. DNA was extracted from $0.5 \mathrm{~g}$ of moist soil using both the PowerSoil DNA Isolation Kit and our in-house method. DNA extractions were conducted four times for each sample and PCR was performed under the optimum conditions for soil samples, as described above. The identifications determined by PCR assay were compared with morphological identifica- tions. A no-DNA template was used as a negative control and DNA from pure nematode cultures was used as positive controls.

\section{RESULTS}

Primer specificity. The primer PNEGF1 designed for $P$. neglectus amplified a unique PCR product (144 bp) with DNA from P. neglectus isolates Pn1, Pn2, Pn3,
Pn4, Pn5, and Pn6 when combined with primer D3B5 but did not produce an amplicon with DNA from $P$. thornei isolates Pt1 and Pt2 (Fig. 1A). As expected, the primer pair $\mathrm{PTHO} / \mathrm{D} 3 \mathrm{~B}$ amplified a specific band (288 bp) from $P$. thornei cultures Pt1 and Pt2 but did not generate an amplicon with DNA from $P$. neglectus cultures Pn1, Pn2, Pn3, Pn4, Pn5, and Pn6

Table 3. Numbers of Pratylenchus neglectus, P. thornei, and other plant-parasitic and non-plantparasitic nematodes extracted from naturally infested soils using the Whitehead tray and morphological identification procedures and polymerase chain reaction (PCR) assays

\begin{tabular}{|c|c|c|c|c|c|c|c|}
\hline \multirow[b]{2}{*}{ Soil $^{\mathrm{c}}$} & \multirow[b]{2}{*}{ Year collected } & \multicolumn{4}{|c|}{ Nematodes/kg of soila } & \multicolumn{2}{|c|}{ PCR assay ${ }^{b}$} \\
\hline & & Pn & $\mathbf{P t}$ & OP & NP & Pn & $\mathbf{P t}$ \\
\hline $\mathrm{S} 1$ & 2007 & 87 & 0 & 1,136 & 3,843 & - & - \\
\hline $\mathrm{S} 2$ & 2007 & 93 & 0 & 0 & 3,988 & - & - \\
\hline $\mathrm{S} 3$ & 2007 & 113 & 0 & 0 & 10,251 & - & - \\
\hline $\mathrm{S} 4$ & 2007 & 343 & 0 & 2,286 & 5,373 & + & - \\
\hline S5 & 2007 & 815 & 0 & 0 & 4,158 & + & - \\
\hline S6 & 2007 & 1,237 & 0 & 0 & 4,948 & + & - \\
\hline S7 & 2007 & 2,697 & 0 & 0 & 4,238 & + & - \\
\hline S8 & 2007 & 3,609 & 570 & 190 & 30,388 & + & + \\
\hline S9 & 2006 & 4,185 & 0 & 135 & 3,240 & + & - \\
\hline $\mathrm{S} 10$ & 2007 & 4,689 & 0 & 408 & 2,854 & + & - \\
\hline $\mathrm{S} 11$ & 2006 & 6,740 & 0 & 124 & 3,463 & + & - \\
\hline $\mathrm{S} 12$ & 2007 & 7,774 & 0 & 2,418 & 11,056 & + & - \\
\hline $\mathrm{S} 13$ & 2007 & 11,118 & 0 & 139 & 2,085 & + & - \\
\hline S14 & 2007 & 13,704 & 98 & 196 & 25,059 & + & - \\
\hline S 15 & 2007 & 16,836 & 324 & 324 & 8,256 & + & + \\
\hline S16 & 2007 & 17,959 & 0 & 770 & 12,828 & + & - \\
\hline S17 & 2007 & 0 & 0 & 2,575 & 3,277 & - & - \\
\hline S18 & 2007 & 0 & 0 & 1,033 & 2,195 & - & - \\
\hline S19 & 2007 & 0 & 0 & 898 & 2,437 & - & - \\
\hline S20 & 2007 & 0 & 117 & 0 & 1,756 & - & - \\
\hline $\mathrm{S} 21$ & 2007 & 0 & 126 & 631 & 1,767 & - & + \\
\hline $\mathrm{S} 22$ & 2006 & 0 & 315 & 473 & 630 & - & + \\
\hline $\mathrm{S} 23$ & 2007 & 0 & 635 & 741 & 4,340 & - & + \\
\hline S24 & 2007 & 0 & 1,936 & 129 & 1,678 & - & + \\
\hline $\mathrm{S} 25$ & 2007 & 0 & 3,277 & 0 & 2,622 & - & + \\
\hline S26 & 2007 & 0 & 4,903 & 0 & 2,790 & - & + \\
\hline S27 & 2007 & 0 & 7,198 & 0 & 1,400 & - & + \\
\hline S28 & 2007 & 0 & 9,430 & 0 & 982 & - & + \\
\hline S29 & 2006 & 0 & 13,721 & 0 & 1,083 & - & + \\
\hline S30 & 2007 & 0 & 15,998 & 0 & 4,081 & - & + \\
\hline
\end{tabular}

${ }^{\text {a }} \mathrm{Pn}=P$. neglectus, $\mathrm{Pt}=P$. thornei, $\mathrm{OP}=$ other plant-parasitic nematodes, and $\mathrm{NP}=$ non-plant-parasitic nematodes.

b Presence $(+)$ or absence $(-)$ of Pn $(144 \mathrm{bp})$ or Pt $(288 \mathrm{bp})$ were detected by PCR using PNEGF1/D3B5 or PTHO/D3B, respectively.

c Soils were collected in Morrow (S1-S16) and Umatilla (S17-S30) Counties of Oregon.

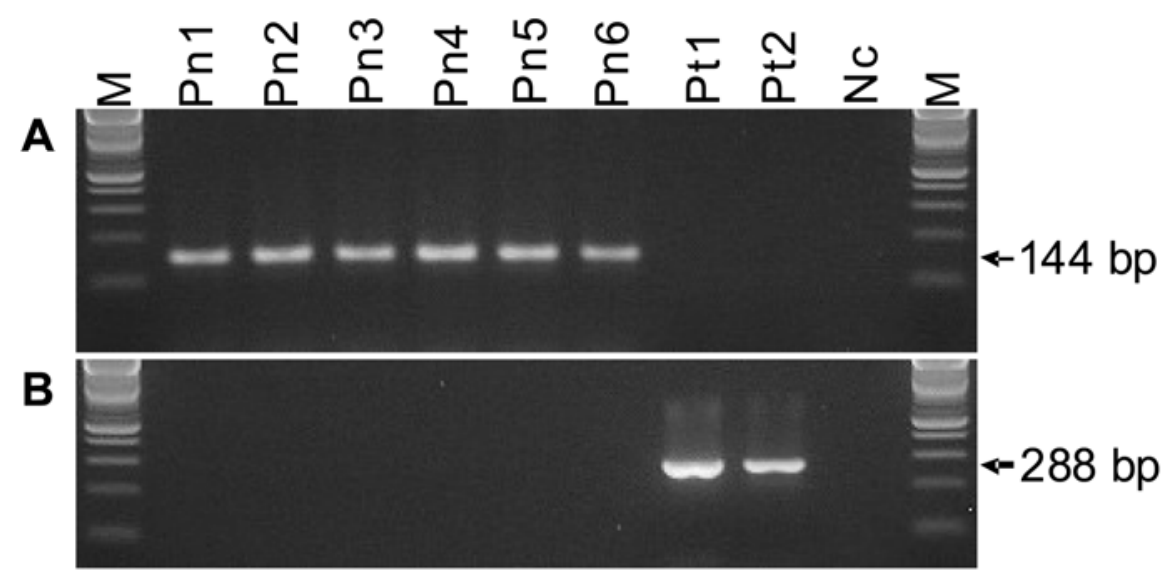

Fig. 1. Specific polymerase chain reaction amplification for Pratylenchus neglectus (144 bp) and $P$. thornei $(288 \mathrm{bp}$ ) from pure cultures using species-specific primers. A, Amplified with P. neglectusspecific primer set PNEG-F1/D3B5. B, Amplified with $P$. thornei-specific primer pair PTHO/D3B. DNA templates from the isolates Pn1, Pn2, Pn3, Pn4, Pn5, Pn6, Pt1, and Pt2 (Table 2) were used. Nc: negative control without DNA template; M: 100-bp DNA molecular weight ladder. 
(Fig. 1B). The sizes of the specific PCR fragments were consistent with those inferred from the nucleotide sequences. Furthermore, no specific PCR product was observed when tested with DNA extracted from five other nontarget Pratylenchus spp. (a total of seven isolates) and three Meloidogyne spp. (Table 2). Similarly, no specific PCR product was produced with DNA from five other plant-parasitic nematode species $(H$. avenae, $H$. filipjevi, Tylenchorhynchus sp., Merlinius brevidens, and Paratylenchus sp.), three nematode communities extracted from local wheat field soils, and six fungal species (Table 2). In silico analysis with four other related Pratylenchus spp. and six species in four nematode genera showed that the new species-specific primer PNEG-F1 does not form hybrids with the sequences of these nontarget organisms because the stability values $(\Delta G)$ obtained for these nontarget hybrids were below the default stability cut-off $(-33 \mathrm{kcal} / \mathrm{mol})$.
DNA extraction from soil. Both commercial kits and all extraction buffers tested in this study allowed the detection of P. thornei and P. neglectus in soil (Fig. 2). MoBio PowerSoil DNA Kit (lane 3) generated a slightly brighter PCR band than that by FastDNA SPIN Kit (lane 4). Among the four buffers, buffer D (lane 8) produced the brightest amplification band. Buffer $\mathrm{C}$ that was used for DNA extraction from nematode cultures (lane 7) was least effective, with relatively faint amplification (Fig. 2A). There was no difference in the intensity of bands observed when using the buffer A (lane 5) and buffer B (lane 6). Therefore, we used buffer D in further experiments. Notably, $P$. thornei DNA extracted with buffer D (lane 8) produced an amplification fragment as bright as that with the MoBio PowerSoil DNA Kit (Fig. 2A, lane 3). Similarly, $P$. neglectus DNA extracted from soil with buffer D (lane 8) also produced a band almost as bright as that with

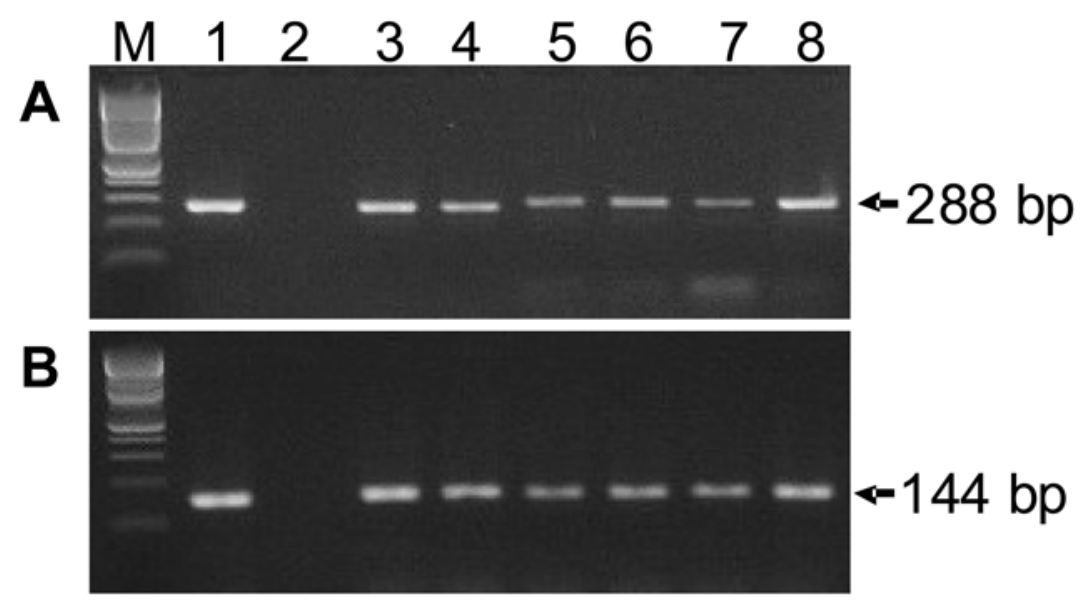

Fig. 2. Effect of DNA extraction methods on polymerase chain reaction (PCR) detection. A, DNA from the soil sample S29 was used for PCR amplification with Pratylenchus thornei-specific primer pair PTHO/D3B: lane 1, positive control using DNA from hand-picked P. thornei. B, DNA from the soil sample S11 was used for PCR amplification with P. neglectus-specific primer set PNEG-F1/D3B5: lane 1, positive control using DNA from hand-picked P. neglectus; lane 2, negative control without DNA template; lane 3, PowerSoil DNA Isolation Kit; lane 4, FastDNA SPIN Kit for Soil; lane 5, buffer A; lane 6, buffer B; lane 7, buffer C; lane 8, buffer D; lane M, 100-bp DNA molecular weight ladder.

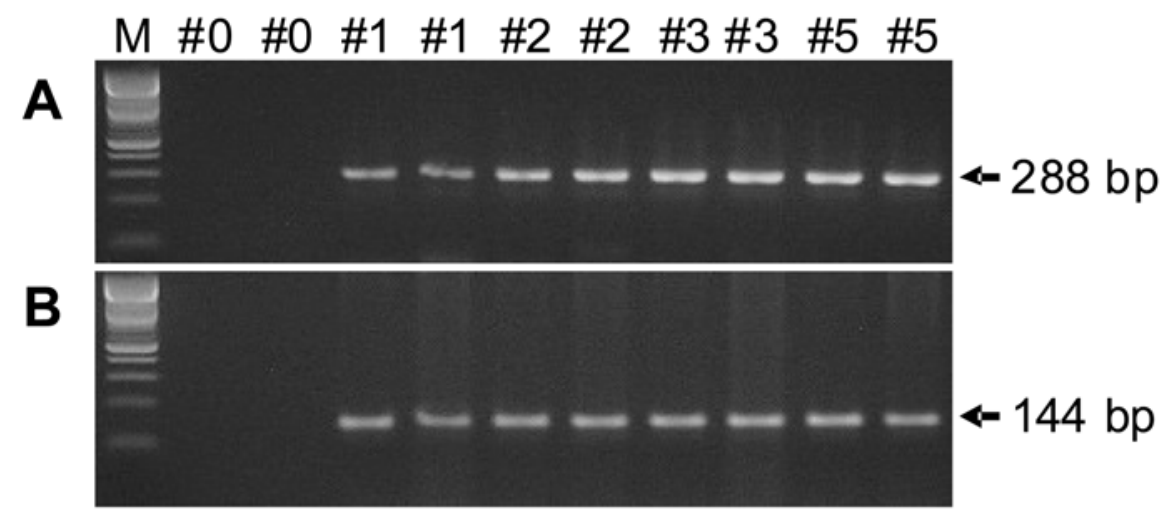

Fig. 3. Level of detection for the polymerase chain reaction amplification in artificially inoculated soils. A, Inoculation of Pratylenchus thornei: zero juvenile (J) (\#0), one J (\#1), two J (\#2), three J (\#3), and five $\mathrm{J}(\# 5)$; B, Inoculation of $P$. neglectus: zero $\mathrm{J}(\# 0)$, one $\mathrm{J}(\# 1)$, two $\mathrm{J}$ (\#2), three $\mathrm{J}$ (\#3), and five J (\#5); M: 100-bp DNA ladder. the MoBio PowerSoil DNA Kit (Fig. 2B, lane 3).

All four treatments using glass beads yielded DNA and allowed the detection of $P$. thornei with the FastPrep FP120 instrument and buffer $\mathrm{D}$. The brightest bands were achieved with $0.53 \mathrm{~g}$ of $1.0-\mathrm{mm}$ glass beads as well as $0.20 \mathrm{~g}$ of $1.0-\mathrm{mm}$ glass beads combined with one ceramic sphere. Minimal amplification resulted from 0.60 $\mathrm{g}$ of 1-mm glass beads combined with 0.15 $\mathrm{g}$ of $0.1-\mathrm{mm}$ glass beads. Intermediate amplification was obtained with $0.80 \mathrm{~g}$ of 1.0-mm glass beads. A similar effect was observed for detection of $P$. neglectus from soil.

Removal of PCR inhibitors in soil. No PCR amplification product was produced with crude DNA extracts obtained with each of the four extraction buffers. To rule out PCR inhibitors co-extracted from soil, PVPP columns were used to replace spin filters provided in commercial kits. After centrifugation at $400 \times g$, DNA extracts from all samples produced visible amplicons without further dilution of the DNA extracts. Higher speed $(720 \times g)$ centrifugation for 5 min resulted in DNA extracts that could not be amplified with the same PCR conditions.

PCR amplification of nematode DNA from soil. In spite of the special PVPP purification step, PCR amplification from soil extracts with the $P$. neglectus-specific primer set was relatively weak compared with that from nematode pure cultures. To improve the amplification, BSA was added to the PCR reaction mixtures at different concentrations $(0.1,0.4,0.8$, and 1.0 $\mu \mathrm{g} / \mu \mathrm{l})$. No marked difference was observed for the band intensity between different concentrations of BSA; however, the presence of BSA enhanced PCR amplification over control samples. The effect of BSA on PCR using DNA extracted with our inhouse method was more evident than on DNA extracted with the PowerSoil DNA Isolation Kit. The addition of BSA (0.8 $\mu \mathrm{g} / \mu \mathrm{l})$ also allowed amplification at a wider range of DNA concentrations, from 0.1 to $2.7 \mathrm{ng} / \mu \mathrm{l}$. In contrast, detection of $P$. thornei from soil could be achieved without BSA. However, PCR amplification for $P$. thornei required a lower concentration of DNA from 0.1 to $0.5 \mathrm{ng} / \mu \mathrm{l}$.

Detection sensitivity of the PCR reaction in artificially inoculated soils. Varying numbers of $P$. neglectus and $P$. thornei juveniles ( $n=1,2,3$, and 5) were inoculated into $1 \mathrm{~g}$ of sterile soils. Specific bands were amplified from all levels of the inoculation for both species even when one nematode was added (Fig. 3). No band was generated from the control soil (sterilized but not inoculated). The PCR test can detect one $P$. neglectus juvenile per gram of soil in seven of the eight independent DNA extractions and one $P$. thornei juvenile per gram of soil in $100 \%$ of the assays. This detection sensitivity equates to half the 
estimated economic threshold $(2,000$ nematodes $/ \mathrm{kg}$ of soil) for natural infestations in dryland fields in the Pacific Northwest (30). The specific amplicons were produced in each of the eight replicates for the other inoculum levels.

Discrimination of $P$. neglectus and $P$. thornei in naturally infested soils. The developed protocol was validated for detecting and discriminating $P$. neglectus and $P$. thornei in 30 soil samples harboring a range of population densities, from 0 to $17,959 P$. neglectus $/ \mathrm{kg}$ of soil and 0 to 15,998 P. thornei $/ \mathrm{kg}$ of soil. In all, 2 of 16 soil samples (Table 3, S4 and S5) from the Morrow County field sites produced bands with the same size as the $P$. neglectuspositive control (144 bp) in three of the four independent DNA extractions when tested with PNEG-F1/D3B5. Eleven samples (S6 to S16) produced the expected amplicons in each replicate with PNEGF1/D3B5. The other three samples (S1 to S3) did not produce the expected amplicon in any of the replicates. The limit of PCR detection for $P$. neglectus was 343 nematodes $/ \mathrm{kg}$ of soil, as determined by the Whitehead tray method. The specific amplicon was not produced in any of the four replicates with the $P$. thornei-specific primer set PTHO/D3B for all except two samples. The amplicons were evident for these two samples (S8 and S15), which also contained 570 and $324 P$. thornei $/ \mathrm{kg}$ of soil, respectively, as determined by the Whitehead tray method. DNA from 2 of 14 samples (Table 3, S21 and S22) collected from Umatilla County sites generated the expected $P$. thornei amplicon (288 bp) in three of the four replicates when amplified with PTHO/D3B. DNA from eight samples (S23 to S30) also generated the expected $P$. thornei amplicon in each replicate. Sample S20 did not produce the expected amplicon in any of the replicates. The limit of PCR detection for $P$. thornei was 126 nematodes $/ \mathrm{kg}$ of soil. The specific amplicon was not observed for the samples from S20 to S30 in any of the replicates with PNEGF1/D3B5. Soil samples (S17, S18, and S19) that had no $P$. neglectus and $P$. thornei, according to the Whitehead tray method, also did not produce the specific amplicons in each replicate when tested with both primer pairs, confirming the specificity of the primers even with the presence of DNA from other plant-parasitic and nonparasitic nematodes in the samples (Table 3). The banding patterns for DNA extractions from nine soil samples obtained by our in-house DNA extraction assay and tested with both species-specific PCR primer sets is shown in Figure 4A. A similar banding pattern was observed for these DNA extractions obtained by the PowerSoil DNA isolation kit (Fig. 4B).

\section{DISCUSSION}

Two plant-parasitic root-lesion nematodes, $P$. neglectus and $P$. thornei, were detected and discriminated in a variety of soil samples using a DNA extraction and PCR amplification method developed in this study. This approach utilized mechanical disruption of nematodes within the soil sample in the FastPrep homogenizer, extracted DNA from soil with or without the use of a commercial kit, and applied species-specific primers to detect multicopy DNA of the target Pratylenchus spp. The assays were sensitive, reliably detecting one juvenile of genomic DNA in $1 \mathrm{~g}$ of sterile, inoculated soil. The assays also proved highly specific when evaluated against template DNA from a range of nematode and fungal species that are common in wheat fields in the Pacific Northwest. Although PCR assays to discriminate Pratylenchus spp. have been previously reported $(1,6,32,37)$, they were not evaluated for detecting $P$. neglectus and $P$. thornei directly from soil.

For $P$. thornei, the species-specific primer PTHO described by Al-Banna et al. (1) was used. This primer produced a spe- cific amplicon with $P$. thornei DNA but did not amplify DNA from other closely related Pratylenchus spp., including $P$. neglectus, $P$. brachyurus, $P$. penetrans, $P$. scribneri, and $P$. vulnus (1). For P. neglectus, the species-specific primer PNEG-F1 was designed from the variable region of D3 expansion domain of the 28S rRNA. No cross reactivity was observed between the sequence of this primer and DNA from other closely related Pratylenchus spp. reported in the Pacific Northwest by in silico analysis. Moreover, when challenged with five other nontarget Pratylenchus spp., eight nematode species in other genera, three nematode communities, and six fungal species, the specific amplicons were not produced. DNA from three soil samples that did not contain $P$. neglectus and $P$. thornei but had other plant-parasitic and non-plant-parasitic nematodes typical of dryland wheat fields in eastern Oregon also did not yield the specific amplicons, demonstrating the specificity of the primers in the soil community complex. Further
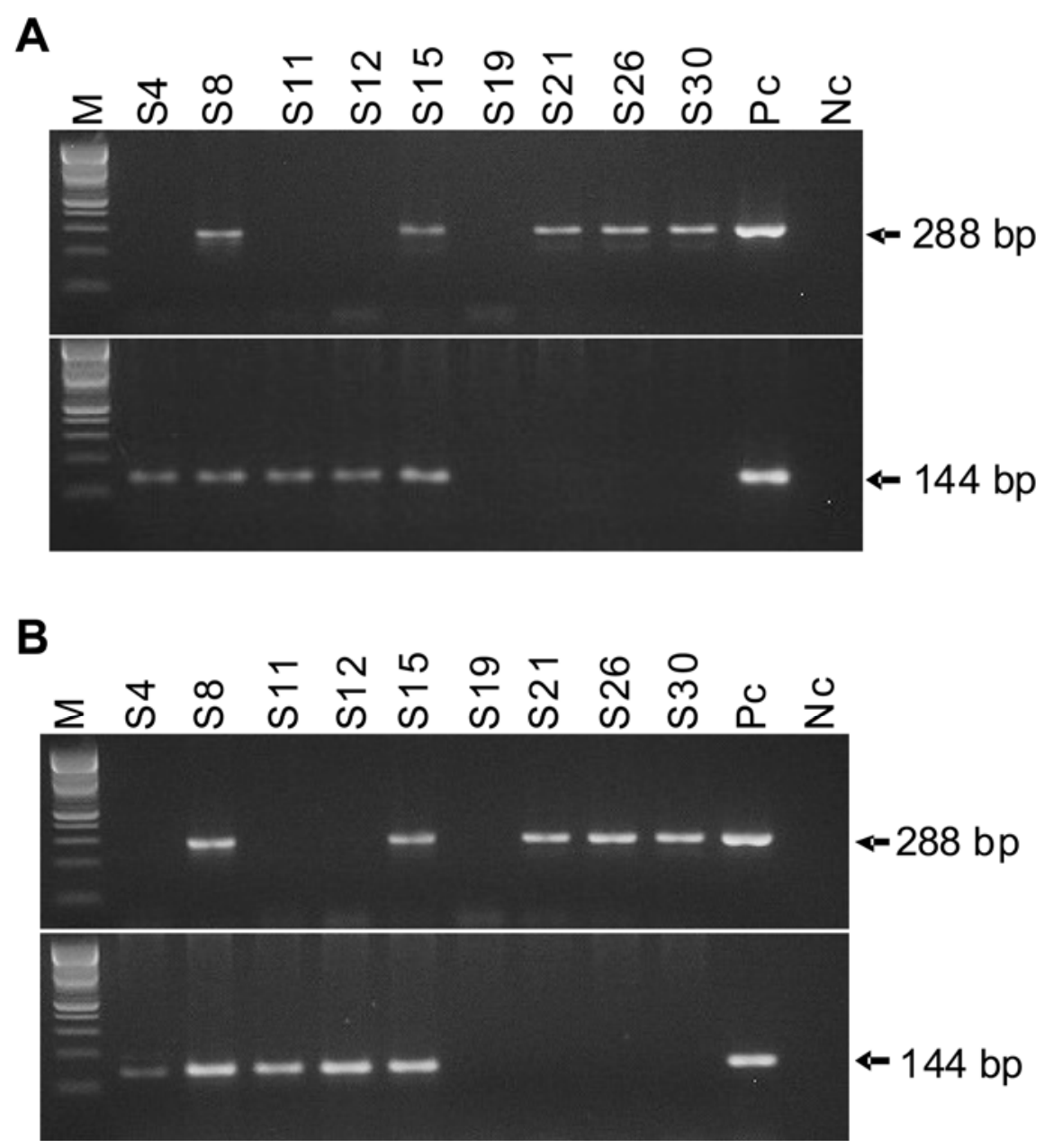

Fig. 4. Identification of Pratylenchus thornei and P. neglectus in naturally infested soil samples. A, Nematode DNA was extracted from soil without any components of a commercial kit. DNA was amplified with the $P$. thornei-specific primer set PTHO/D3B (top) and with the P. neglectus-specific primer set PNEG-F1/D3B5 (bottom). B, Nematode DNA was extracted from soil with the PowerSoil DNA Isolation Kit. DNA was amplified with the P. thornei-specific primer set PTHO/D3B (top) and with the P. neglectus-specific primer set PNEG-F1/D3B5 (bottom). The soil samples S4, S8, S11, S12, S15, S19, S21, S26, and S30 were shown in Table 3. Pc: positive control from nematode culture; Nc: negative control without DNA template. 
testing of these primers with local species may be necessary if these primers were used for PCR identification with DNA extracts from soil in other areas.

Published species-specific primers (1) produced PCR fragments with very little difference (2 bp) in length for the two Pratylenchus spp. due to the use of a common reverse primer, D3B. Therefore, we designed a reverse primer D3B5 from the conserved sequences of $28 \mathrm{~S}$ rRNA D3 expansion region. This resulted in PCR fragments that had larger size differences that could be easily separated by agarose gel electrophoresis. Additionally, the forward primer PNEG-F1 for $P$. neglectus proved to be more sensitive and robust for detection of DNA from soil extracts than the PNEG primer described by Al-Banna et al. (1) at the annealing temperature of $60^{\circ} \mathrm{C}$.

The DNA extraction method developed in this study was based on the method of Damm and Fourie (11), which was developed to extract DNA from the soilborne fungal pathogens Phaeomoniella chlamydospora and Cylindrocarpon spp. With some modifications, we used this protocol to extract Pratylenchus neglectus and $P$. thornei DNA from soil for PCR detection. Adding $0.53 \mathrm{~g}$ of $1.0-\mathrm{mm}$ glass beads or $0.20 \mathrm{~g}$ of $1.0-\mathrm{mm}$ glass beads combined with one ceramic sphere to the extraction buffer increased the amplification intensity. Considering the relative cost of a ceramic sphere, $0.53 \mathrm{~g}$ of $1.0-\mathrm{mm}$ glass beads were selected in place of the lysing matrix provided in FastDNA SPIN Kit. Glass beads aided in the disruption or shearing of the nematode cuticle, allowing release of DNA. Cullen and Hirsch (9) reported that the use of bead-beating in the cell lysis step increased the DNA yield and also decreased the amount of humic compounds when monitoring a Rhizobium leguminosarum bv. viciae strain RSM2004 in Rothamsted field soils. Kageyama et al. (15) reported that adding $0.2 \mathrm{~g}$ of $1-\mathrm{mm}$ glass beads to the extraction buffer was necessary for detecting Verticillium dahliae in soil.

Purification of DNA from soil was essential for detecting the two target nematode species. Two merits of the DNA purification method developed in this study are that (i) it does not require the expensive Micro Bio-Spin column or Sephadex G-75 used by Cullen et al. (10) and (ii) it is easy to prepare the PVPP column. Extraction of DNA from soil frequently results in coextraction of humic substances that interfere with PCR amplification $(9,11,33)$. PVPP is an inexpensive chemical that can be utilized for eliminating the majority of humic and fulvic acids because it binds phenolic compounds (9-11). Commercial soil DNA extraction kits are expensive (e.g., the cost of the MOBio PowerSoil DNA kit is approximately $\$ 4.16$ per reaction). Our in-house assay, using buffer D (phosphate and SDS buffer), $0.53 \mathrm{~g}$ of 1.0mm disruption glass beads, glass wool, and purification column with dry PVPP powder yielded PCR-quality DNA that was comparable with that yielded by the PowerSoil DNA kit. The estimated cost for one reaction is $\$ 0.30$, which greatly reduces the cost of DNA extraction and purification from soil.

The effect of BSA on PCR amplification was different for the two target nematode species at lower DNA concentrations $(0.1$ to $0.5 \mathrm{ng} / \mu \mathrm{l})$. BSA greatly enhanced detection of $P$. neglectus in soil, whereas $P$. thornei could be detected without the addition of BSA. The effect of BSA on PCR was not correlated with BSA concentrations. Similarly, Kageyama et al. (15) found that BSA was essential for detecting $V$. dahliae and enhanced detection of $P y$ thium ultimum but was not necessary for detecting Plasmodiophora brassicae in soil. BSA is thought to stabilize Taq polymerase and neutralize inhibitory contaminants $(11,16,19,24)$.

PCR detected one juvenile in $1 \mathrm{~g}$ of sterile, inoculated soil, equating to 1,000 juveniles $/ \mathrm{kg}$ of soil. It could detect even lower densities of nematodes in naturally infested soil: 126 Pratylenchus thornei nematodes $/ \mathrm{kg}$ of soil and 343 P. neglectus nematodes $/ \mathrm{kg}$ of soil. The discrepancy between artificially inoculated soil and naturally infested soil may be due to differences in sample size and nematode counting methods used. One juvenile was the minimum number of nematodes that can be added into $1 \mathrm{~g}$ of sterile soil, whereas the number of target nematodes from natural soil was obtained using the Whitehead tray method by counting the number of nematodes per milliliter of suspension extracted from approximately 200 $\mathrm{g}$ of soil and converting to the number in 1 $\mathrm{kg}$ of soil. More importantly, the detection sensitivity was much lower than the economic threshold level (2,000 nematodes/kg of soil) in the Pacific Northwest (30), indicating that this method could be useful for disease forecasting and management. This sensitivity was higher than recent reports for Meloidogyne and Nacobbus spp., where the level of detection was 5,000 juveniles $/ \mathrm{kg}$ of soil (14) and 30,000 juveniles/kg of soil (4), respectively.

During the present study, the presence of $P$. neglectus and $P$. thornei was successfully detected in most of the soil samples taken from Morrow County or Umatilla County, Oregon. Each pathogen was specifically detected in naturally infested field soils that contained a higher number of nematodes than the respective detection limits. Particularly, two soil samples were infested with both $P$. neglectus and $P$. thornei and, accordingly, the two species were detected by PCR. Compared with the Whitehead tray method and subsequent microscopic identification, the lack of $P$. neglectus DNA detection for $\mathrm{S} 1, \mathrm{~S} 2$, and
S3 or the lack of $P$. thornei DNA detection for S20 by PCR is probably due to the uneven distribution of nematodes in soil (23) and the small amount of soil $(\leq 1 \mathrm{~g})$ that can be processed in the FastPrep FP120 homogenizer. However, the Whitehead tray method requires a minimum of $48 \mathrm{~h}$ to extract approximately $60 \%$ of the nematode population from silt loams, and it may take as many as 6 days to extract all nematodes (5). In contrast, DNA extraction and PCR amplification, as used in this study, require 5 to $6 \mathrm{~h}$.

Pratylenchus spp.-infested soil represents a serious threat to intolerant wheat cultivars. Therefore, the detection and discrimination of these nematodes in soil are very important in the Pacific Northwest. The molecular method developed in this study allows nematode DNA to be extracted directly from soil, facilitating the rapid and inexpensive detection and identification of $P$. neglectus and $P$. thorne $i$ with equipment commonly available in research and commercial laboratories. In commercial labs, Pratylenchus spp. are often quantified at the genus level, which is now recognized as inadequate for serving wheatbased agricultural systems where Pratylenchus spp.-specific tolerance and resistance are being developed. This PCRbased diagnostic method has the potential for implementation in commercial as well as research applications. Protocols reported here are being adapted for use in real-time PCR applications, thus enabling labs to avoid physical separation, microscopic identification, and counting of $P$. neglectus and $P$. thornei from soil.

\section{ACKNOWLEDGMENTS}

This research was supported by the Oregon State University, Agricultural Research Foundation project ARF 7117, and a contract with the USDAARS (SCA 58-5348-9-100, "Control of Root Diseases of Wheat and Barley"), and USDA-ARS Project No. 5248-22000-012-00D (P.A.O.). We thank S. H. Hulbert and C. Yin at Washington State University for use of the NanoDrop ND-1000 Spectrophotometer; A. Dyer, S. Hafez, L. Carta, Z. Handoo, W. Klassen, A. MacGuidwin, K. Merrifield, E. Riga, and M. Mazzola for providing isolates of control nematodes and fungi; and C. Watson for technical support.

\section{LITERATURE CITED}

1. Al-Banna, L., Ploeg, A. T., Williamson, V. M., and Kaloshian, I. 2004. Discrimination of six Pratylenchus species using PCR and speciesspecific primers. J. Nematol. 36:142-146.

2. Al-Banna, L., Williamson, V., and Gardner, S. L. 1997. Phylogenetic analysis of nematodes of the genus Pratylenchus using nuclear $26 \mathrm{~S}$ rDNA. Mol. Phylogenet. Evol. 7:94-102.

3. Amiri, S., Subbotin, S. A., and Moens, M. 2002. Identification of the beet cyst nematode Heterodera schachtii by PCR. Eur. J. Plant Pathol. 108:497-506.

4. Atkins, S. D., Manzanilla-López, R. H. Franco, J., Peteira, B., and Kerry, B. R. 2005. A molecular diagnostic method for detecting Nacobbus in soil and in potato tubers. Nematology 7:193-202.

5. Bell, N. L., and Watson, R. N. 2001. Optimising the Whitehead and Hemming tray method to extract plant parasitic and other nematodes 
from two soils under pasture. Nematology 3:179-185.

6. Carrasco-Ballesteros, S., Castillo, P., Adams, B. J., and Pérez-Artés, E. 2007. Identification of Pratylenchus thornei, the cereal and legume root-lesion nematode, based on SCAR-PCR and satellite DNA. Eur. J. Plant Pathol. 118:115-125.

7. Carta, L. K., Skantar, A. M., and Handoo, Z. A. 2001. Molecular, morphological and thermal characters of 19 Pratylenchus SPP. and relatives using the D3 segment of the nuclear LSU rRNA gene. Nematropica 31:193-207.

8. Castillo, P., and Vovlas, N. 2008. Pratylenchus, Nematoda, Pratylenchidae: diagnosis, biology, pathogenicity and management. Nematol. Monogr. Perspect. 6:1-530.

9. Cullen, D. W., and Hirsch, P. R. 1998. Simple and rapid method for direct extraction of microbial DNA from soil for PCR. Soil Biol. Biochem. 30:983-993.

10. Cullen, D. W., Lees, A. K., Toth, I. K., and Duncan, J. M. 2001. Conventional PCR and real-time quantitative PCR detection of Helminthosporium solani in soil and on potato tubers. Eur. J. Plant Pathol. 107:387-398.

11. Damm, U., and Fourie, P. 2005. A costeffective protocol for molecular detection of fungal pathogens in soil. S. Afr. J. Sci. 101:135-139.

12. Filho, A. C. C., and Huang, C. S. 1989. Description of Pratylenchus pseudofallax n. sp. with a key to species of the genus Pratylenchus Filipjev, 1936 (Nematoda: Pratylenchidae). Rev. Nématol. 12:7-15.

13. Handoo, Z. A., and Golden, A. M. 1989. A key and diagnostic compendium to the species of the genus Pratylenchus Filpjev, 1936 (lesion nematodes). J. Nematol. 21:202-218.

14. Iwahori, H., Tateishi, Y., and Uesugi, K. 2006. Effective method for direct extraction of DNA from soil and detection of root-knot nematode by PCR-RFLP. (Abstr.) Proc. 27th Int. Symp. Eur. Soc. Nematol.

15. Kageyama, K., Komatsu, T., and Suga, H. 2003. Refined PCR protocol for detection of plant pathogens in soil. J. Gen. Plant Pathol. 69:153-160.

16. Kreader, C. A. 1996. Relief of amplification inhibition in PCR with bovine serum albumin of T4 gene 32 protein. Appl. Environ. Microbiol. 62:1102-1106

17. Mai, W. F., Mullin, P. G., Lyon, H. H., and Loeffler, K. 1996. Plant-Parasitic Nematodes: A Pictorial Key to Genera. Cornell University Press, Ithaca, NY.

18. Matsunaga, K., and Togashi, K. 2004. A simple method for discriminating Bursaphelenchus xylophilus and B. mucronatus by speciesspecific polymerase chain reaction primer pairs. Nematology 6:273-277.

19. Nagai, M., Yoshida, A., and Sato, N. 1998. Additive effects of bovine serum albumin, dithiothreitol and glycerol on PCR. Biochem. Mol. Biol. Int. 44:157-163.

20. Okubara, P. A., Schroeder, K. L., and Paulitz, T. C. 2008. Identification and quantification of Rhizoctonia solani and $R$. oryzae using realtime polymerase chain reaction. Phytopathology 98:837-847.

21. Ophel-Keller, K., McKay, A., Hartley, D., Herdina, and Curran, J. 2008. Development of a routine DNA-based testing service for soilborne diseases in Australia. Australas. Plant Pathol. 37:243-253.

22. Orui, Y. 1996. Discrimination of the main Pratylenchus species (Nematoda: Pratylenchidae) in Japan by PCR-RFLP analysis. Appl. Entomol. Zool. 31:505-514.

23. Qiu, J. J., Westerdahl, B. B., Anderson, C., and Williamson, V. 2006. Sensitive PCR detection of Meloidogyne arenaria, $M$. incognita, and $M$. javanica extracted from soil. J. Nematol. 38:434-441.

24. Ralser, M., Querfurth, R., Warnatz, H.-J, Lehrach, H., Yaspo, M.-L., and Krobitsch, S. 2006. An efficient and economic enhancer mix for PCR. Biochem. Biophys. Res. Commun. 347:747-751.

25. Rivoal, R., Valette, S., Bekal, S., Gauthier, J.P., and Yahyaoui, A. 2003. Genetic and phenotypic diversity in the graminaceous cyst nematode complex, inferred from PCR-RFLP of ribosomal DNA and morphometric analysis. Eur. J. Plant Pathol. 109:227-241.

26. Schroeder, K. L., Okubara, P. A., Tambong, J. T., Lévesque, C. A., and Paulitz, T. C. 2006. Identification and quantification of pathogenic Pythium spp. from soils in eastern Washington using real-time polymerase chain reaction. Phytopathology 96:637-647.

27. Smiley, R. W., Merrifield, K., Patterson, L-M., Whittaker, R. G., Gourlie, J. A., and Easley, S. A. 2004. Nematodes in dryland field crops in the semiarid Pacific Northwest United States. J. Nematol. 36:54-68

28. Smiley, R. W., and Nicol, J. M. Nematodes which challenge global wheat production. In: Wheat: Science and Trade. B. F. Carver, ed. Blackwell Publishing Co., Ames, IA. In press.

29. Smiley, R. W., Whittaker, R. G., Gourlie, J. A., and Easley, S. A. 2005. Pratylenchus thornei associated with reduced wheat yield in Oregon. J. Nematol. 37:45-54.

30. Smiley, R. W., Whittaker, R. G., Gourlie, J. A., and Easley, S. A. 2005. Suppression of wheat growth and yield by Pratylenchus neglectus in the Pacific Northwest. Plant Dis. 89:958-968.

31. Strausbaugh, C. A., Bradley, C. A., Koehn, A C., and Forster, R. L. 2004. Survey of root diseases of wheat and barley in southeastern Idaho. Can. J. Plant Pathol. 26:167-176.

32. Subbotin, S. A., Ragsdale, E. J., Mullens, T. Roberts, P., and Baldwin, J. G. 2007. Molecular diagnostics and phylogenetic relationships of some species of root-lesion nematodes of the genus Pratylenchus. (Abstr.) J. Nematol. 39:80.

33. Tebbe, C. C, and Vahjen, W. 1993. Interference of humic acids and DNA extracted directly from soil in detection and transformation of recombinant DNA from bacteria and a yeast. Appl. Environ. Microbiol. 59:2657-2665.

34. Thompson, J. P., Owen, K. J., Stirling, G. R., and Bell, M. J. 2008. Root-lesion nematode (Pratylenchus thornei and $P$. neglectus): a review of recent progress in managing a significant pest of grain crops in northern Australia. Australas. Plant Pathol. 37:235-242.

35. Uehara, T., Mizukubo, T., Kushida, A., and Momota, Y. 1998. Identification of Pratylenchus coffeae and $P$. loosi using specific primers for PCR amplification of ribosomal DNA. Nematologica 44:357-368.

36. Vanstone, V. A., Hollaway, G. J., and Stirling, G. R. 2008. Managing nematode pests in the southern and western regions of the Australian cereal industry: continuing progress in a challenging environment. Australas. Plant Pathol 37:220-234..

37. Waeyenberge, L., Ryss, A., Moens, M., Pinochet, J., and Vrain, T. C. 2000. Molecular characterization of 18 Pratylenchus species using rDNA restriction fragment length polymorphism. Nematology 2:135-142.

38. Waite, I. S., O'Donnell, A. G., Harrison, A., Davies, J. T., Colvan, S. R., Ekschmitt, K. Dogan, H., Wolters, V., Bongers, T., Bongers, M., Bakonyi, G., Nagy, P., Papatheodorou, E. M., Stamou, G. P., and Boström, S. 2003. Design and evaluation of nematode 18S rDNA primers for PCR and denaturing gradient gel electrophoresis (DGGE) of soil community DNA. Soil Biol. Biochem. 35:1165-1173.

39. Whitehead, A. G., and Hemming, J. R. 1965. A comparison of some quantitative methods of extracting small vermiform nematodes from soil. Ann. Appl. Biol. 55:25-38.

40. Zijlstra, C. 2000. Identification of Meloidogyne chitwoodi, M. fallax, and M. hapla based on SCAR-PCR: a powerful way of enabling reliable identification of populations or individuals that share common traits. Eur. J. Plant Pathol. 106:283-290. 